\title{
The Implementation of Students' Hard Work and Responsible Characters in Civic Education Learning in SMP Islam Karangrayung of Grobogan Regency
}

\author{
$1^{\text {st }}$ Citra Megananda \\ Department of Education \\ Administration of Postgraduate \\ School Universitas \\ Muhammadiyah Surakarta, \\ Indonesia, 57102 \\ citramegananda@gmail.com
}

\author{
$2^{\text {nd }}$ Bambang Sumardjoko \\ Department of Education \\ Administration of Postgraduate \\ School Universitas \\ Muhammadiyah Surakarta, \\ Indonesia, 57102 \\ bs131@ums.ac.id
}

\author{
$3^{\text {rd }}$ Ahmad Muhibbin \\ Department of Education \\ Administration of Postgraduate \\ School Universitas \\ Muhammadiyah Surakarta, \\ Indonesia, 57102 \\ am215@ums.ac.id
}

\begin{abstract}
This research aimed to describe implementation, constraint, and solution to the constraint in the implementation of hard work and responsibility character education in Civic Education learning in students of SMP Islam Karangrayung Grobogan. This study was a descriptive qualitative research with ethnographic approach. Techniques of collecting data used were interview, observation, and documentation. Data validation was carried out using source and technique triangulations. Data analysis was conducted using interactive model. The result of research was described as follows. Firstly, the implementation of hard work and responsibility character education starts with planning and preparing RPP (Learning Implementation Plan). Its implementation was conducted through role modeling and motivating. Evaluation was conducted by considering cognitive, affective, and psychomotor developments of students using observation sheet. Secondly, the constraints found in the implementation of hard work character were having no priority, perfectionistic characteristic, less focus, and poor time management. The constraints encountered in responsibility character education included students themselves and their peer. Thirdly, the solution to the constraints in the implementation of hard work character included role modeling, understanding, sanction, motivation, creating conducive class circumstance, warning, due time, and helping the sluggish students. Meanwhile, solution to the constraints in the implementation of responsibility character included consequence imposition, briefing, and punishment.
\end{abstract}

Keywords - civic education; hard work character; responsibility

\section{INTRODUCTION}

Character education still becomes a hot topic for many people, including educators, until today. The phenomenon appearing recently is that moral behavior of adolescents is increasingly fading. Violence in the form of quarrel between adolescents, low respect to elders and teachers, increasingly culturing dishonesty, suspicion, and low responsibility in both individual and group are several examples of adolescent behavior appearing recently.

Education plays a very strategic role in improving the quality of human resource. Education is an attempt of bringing Indonesians' ideal into reality, public welfare, and of educating the life of the people. A nation's advance is also dependent on the character the next generation has. It is because character can create the quality ofhuman resource thereby resulting in a community having superior skill. Character is mental traits, akhlak or noble character distinguishing an individual from another (Samani and Haryanto, 2012: 42).

Article 3 of Law Number 20 of 2003 mentions that character education is established as one of education programs consistent with function and objective of National Education System as follows:

To develop ability and to create the nation's dignified disposition and civilization in the attempt of educating the life of people aiming to develop the students' potency in order to be human beings who are faithful and cautious to the One and Only God, having noble character, healthy, knowledgeable, creative, independent, and becoming democratic and responsible citizens. 
The main objective of character education is to facilitate the reinforcement and development of certain values thereby being manifested into child's behavior either during or after learning process at school. The next objective of character education is to correct student behavior inconsistent with values developed by school. School attempts to achieve the objective through many subjects including Pancasila and Civic Education. Pancasila and Civic Education subject is one of appropriate subjects to apply character education program.

Civic education is a subject focusing on diverse self-development viewed from religion, socialcultural, language, age, and ethnic aspects in order to be Indonesian citizens that are smart, skilled, and have good character as mandated by Pancasila and 1945 Constitution. As a subject, Civic Education as vision and mission becoming guidelines. The vision of Civic Education is as follows: Hard work and responsibility constitutes important character the next generation should have, particularly those who still study at school. Having both characters enable the students to achieve good performance in both academic and non-academic field. Hard work is "a behavior indicating a sincere attempt of dealing with many constraints in completing the task as well as possible (Mustari, 2014:43). Meanwhile, responsibility is an individual's attitude and behavior to implement his/her duty and obligation duly to $\mathrm{him} /$ herself, community, environment (nature, social and culture), state, and God (Gunawan, 2012: 33).

Pancasila and Civic Education subject teaches about Indonesian nation and how Indonesians should behave. However, recently Civic Education subject is underestimated and people consider that this subject is not too important compared with other subject. In learning practice, students sometimes pay less attention to the material delivered by teacher. It inhibits the achievement of expected learning objective.

Considering the background above, the author conducts a research on "The Implementation of Hard Work and Responsibility Character Education in the Students in Civic Education learning in SMP Islam Karangrayung Grobogan". Meanwhile, the objective of research is to describe the implementation of hard work and responsibility character education, the constraints with the implementation of hard work and responsibility character education, and the solution to the constraints with the implementation of hard work and responsibility character education in the Students in Civic Education learning in SMP Islam Karangrayung Grobogan.

\section{METHOD}

This study was a descriptive qualitative research with ethnographic design. Mantja (2005: 2) says that ethnography is the reconstruction of a human group's culture or anything considered as culture in many aspects of human life. This ethnographic study attempted to understand the implementation of hard work and responsibility character education in the Students in Civic Education in SMP Islam Karangrayung Grobogan. Technique of collecting data used was an interactive model including interview, observation, and documentation. Data validation was conducted firstly using source triangulation, constituting information from place, event, and document containing notes related to data intended. Secondly, it was conducted using technique triangulation by means of checking the data resulting from interview, observation and document. Data analysis was carried out using interactive model encompassing data reduction, data display, and conclusion drawing.

\section{RESULTS AND DISCUSSION}

Implementation of hard work and responsibility character education in the Students in Civic Education lea

A. Planning of hard work and responsibility character education

The planning of the implementation of hard work and responsibility character education in the Students in Civic Education in SMP Islam Karangrayung Grobogan was done by teacher by means of preparing and organizing RPP (Learning Implementation Plan) adjusted with prevailing curriculum. The learning in the 7 th grade uses 2013 curriculum and in the 8th and 9th grade uses KTSP (Educational Unit Level Curriculum). The RPP includes values related to hard work and responsibility character clearly. Both character values can be seen in RPP exactly in basic competency and indicator, material, procedure, and learning evaluation sections. It is in line with Triyono's (2012) study concluding that the integration of character education into German language learning can be accomplished by means of developing syllabus and RPP containing values.

The inclusion of responsibility character values into RPP in SMP Islam Karangrayung is in line with Ardaiolo (2011) concluding that responsibility teaching is performed by preparing collaboration and learning experience program for students corresponding to curriculum. Educating personal and social responsibility is "the heart" of educated citizens and it should be taught. In addition, the process of developing RPP found in this study has been consistent with Republic of Indonesia National Education Minister's Regulation Number 41 of 2007 about Standard Process of Primary and Secondary Educations explaining that the planning of learning process should include syllabus and learning implementation plan.

Hard work and responsibility characters are the ones a student should have. By having had work, a student will be able to achieve satisfying achievement. Meanwhile, responsibility the 
students have will make them valued and trusted by others. It is in line with Ikhwanuddin's (2012) study concluding that the implementation of hard work and cooperation character education can improve the students' skill and learning achievement. Learning achievement is considered as the side effect of character education in learning process.

B. The implementation of hard work and responsibility character education

The implementation of character education conducted by teacher was conducted by teachers through Teacher's role modeling related to hard work attitude manifested into real attempt during the learning process. The role modeling shown by teacher will be imitated indirectly by students. Teacher's attitude during learning process in the class giving role model related to hard work will be imitated gradually by students. It is in line with Anderson's (2000), concluding that teacher becomes the center of character education. Teacher becomes a role model to his/her students. In addition, role modellinggiven by teacher in implementing character education is also consistent with Bambang Dalyono and Enny Dwi Lestariningsih's (2017) study finding that the implementation of character education reinforcement is conducted by giving role model, learning in the class, and integrating it into all learning materials.

In the implementation of hard work character education, it can be found some attitudes of SMP Islam Karangrayung students during the learning process, in which they completethe assignment timely, deal with the difficulty persistently, check and recheck their work before submitting it to teacher and are capable of managing time they have. It is in line with Curriculum Center of National Education Ministry's Research and Development Agency(2010: 37) suggesting that the forms of hard work character include completing all assignments well and timely, and dealing with the difficulty persistently, and solving problem persistently. In addition, the implementation of hard work character education in this study is also in line with Kesuma's (2012) study finding that indicators of hard work character includes: feeling anxious when their job has not been done completely, checking and rechecking what should be done and what are the responsibility of a position, capable of managing time they have, capable of organizing the resource existing to complete its assignment and to meet its responsibility.

In addition to hard work character, responsibility character education is also found in the students of SMP Islam Karangrayung during Civil Education learning process. Responsibility attitude includingundertaking their obligation duly and having ability of making rational decisionare two attitudes featured in the students of SMP Islam Karangrayung as the implementation of responsibility character. Another responsibility character implemented is trustability. Such the trustability is supported by attitudes of students who work on the assignment wholeheartedly, complete the assignment well and timely, and have honesty in doing any assignment given. This finding is in line with Hidayatullah's (2010:92) study finding that responsibility character has the following indicators: understanding and doing what should do, capable of making rational and moral decision, and having trustability. These attitudes can be called as being responsible. Thus, the factor of role modeling given by teacher is considered as effective in supporting character education that will be delivered to students. The result of research shows that indicator of hard work and responsibility characters can be seen clearly in the students.

C. Evaluation on hard work and responsibility character education

Evaluation is conducted by means of observing the students' attitude during Civic Education learning process, in cognitive, affective and psychomotor aspect. Although the evaluation on hard work and responsibility character education shows many attitudes of students not reflecting the two character, overall, hard work and responsibility characters have been actually appeared in the students. The assessment on hard work and responsibility education is measured using assessment observation sheet prepared. Assessment observation sheet is divided into two: each of characters is adjusted with the target to be achieved in the two character education.

This finding is in line with Maryono's (2015) study stating that monitoring and evaluation on the implementation of character education are conducted in two ways: through participation management system involving all components of school, andthrough academic system in the form of report on activities related to students' cognitive, affective, and psychomotor aspects. Therefore, this research suggests that evaluation on hard work and responsibility character education in Civic Education learning in SMP Islam Karangrayung by utilizing observation sheet in order to facilitate the teacher in observing the students' attitude.

D. The constraints with the implementation of hard work and responsibility character education in Civic Education learning

The implementation of hard work and responsibility character does not always run as expected. Constraints are still found in some parts. The constraints found are, among others, students having no priority in doing assignment, students who are too perfectionistic, having less focused and careless. The students not focusing reading questions in Civic Education learning evaluation, thereby reading the questions carelessly and incapable of answering the 
question correctly. In addition, some students cannot manage time well thereby working on and submitting the assignment in hurry.

Meanwhile, the constraints inhibiting the implementation of responsibility character education in Civic Education learning in students includes internal and external or classmate factors. Internal factor includes students' descent or background. When a student comes from a family having irresponsible or less responsible attitude, he/she will has such the attitude as well. Furthermore, school environment factor, including students' interaction with their friends, affects the creation of students' attitude strongly. It occurs because students spend more time with their friends than with their teachers or parents. This finding is in line with Gunawan's(2012:1922) study suggesting thatthe factor affecting an individual's character creation are divided into two categories: internal and external factors.

E. Solution to the constraints with the implementation of hard work and responsibility character education in Civic Education learning

The constraints the teacher encounters related to the implementation of hard work and responsibility character education should be solved. The first solution the teacher takes is to give role modelling about discipline, giving the students an understanding on the importance of time owned, and punishing the students not completing the assignment timely. Teacher motivates the students during learning process, creates conducive class circumstance, and reminds the students to recheck their work before submitting it. This is in line with Hidayat's (2014) study finding that the solution to deal with the constraints with the implementation of hard work includes providing work environment and improving communication.

The follow-up action taken by the school in dealing with the constraints with the implementation of hard work character education is to punish the students who do not want to do their obligation and assignment. In the meantime, teacher also helps students make decision rationally when they find difficulty in learning and give direction about the importance of being responsible for themselves. It is in line with Kesuma's (2012) study finding that the solutions to the constraints with the implementation ofresponsibility character are to deliver clear message about responsible behavior, to expect and ask for responsibility, not to give "excuse", to determine the consequence imposed when they keep irresponsible, to reinforce behavior and responsible action.

\section{CONCLUSION}

The implementation of hard work character education in the students of SMP Islam Karangrayung in Civic Education learning in the class has run as planned. Students show hard work character by completing all assignments timely, dealing with the difficulty persistently, checking what is done/what is the responsibility. The implementation of responsibility character can be seen from students doing the assignment given, their ability of making decision rationally, and their trustability.

The constraints the students encounter related to the implementation of hard work character education include: having no priority, perfectionistic characteristic, less focus, and poor time management. The constraints encountered in responsibility character education included internal and external factors coming from their friends.

The solution to the constraints related to the implementation of hard work character education includesgiving role model about discipline, giving the students an understanding on the importance of time owned, and giving punishment. Furthermore,teacher motivates the students during learning process, creates conducive class circumstance, and helps sluggish students do the assignment. Meanwhile, the solutions to the constraints with the implementation of responsibility character education are solution to the constraints in the implementation of responsibility character included imposing consequence or punishment to the students who do not want to do their obligation and assignment (duty), helping the students make decision rationally when encountering learning difficulty, and giving direction (briefing) about the importance of being responsible for themselves..

\section{REFERENCES}

[1] Anderson, Donna R. 2000. "Character Education: Who Is Responsible? Academic Journal Article".Journal Of Instructional Psychology.

[2] Ardaiolo. 2011. "Teaching Students Personal And Social Responsibility With Measurable Learning Outcomes". Journal of College and Character, V12 N2 May 2011 ISSN-1940-1639.

[3] Gunawan, Heri. 2012. Pendidikan Karakter Konsep dan Implementasi. Bandung: CV Alfabeta.

[4] Hidayatullah, Furqon. 2010. Pendidikan Karakter: Membangun Peradaban Bangsa. Surakarta: Yuma Pustaka.

[5] Ikhwanuddin. 2012.’'Implementasi Pendidikan Karakter Kerja Keras dan Kerja Sama Dalam Perkuliahan".Jurnal Pendidikan Karakter. Vol 2, Nomor 2.

[6] Kesuma, Dharma dkk. 2011. Pendidikan Karakter Kajian Teori dan Praktik di Sekolah. Bandung: PT Remaja Rosdakarya.

[7] Mantja, W. 2005. Etnografi Desain Penelitian Kualitatif dan Manajemen Pendidikan. Malang: Wineka Media.

[8] Maryono. 2015. "The Implementation of Character Education Policy at Junior High Schools and Islamic Junior High Schools in Pacitan". International Journal of Education and Research. Vol. 3 No. 5. 
[9] Mustari, Mohamad. 2014. Nilai Karakter Refleksi untuk Pendidikan. Jakarta: PT. Raja Grafindo Persada.

[10] Samani, Muchlas dan Hariyanto. 2013. Konsep dan Model Pendidikan Karakter. Bandung: Remaja Rosdakarya.
[11] Triyono, Sulis.2012. "Pengintegrasian Pendidikan Karakter Dalam Pembelajaran Bahasa Jerman".Jurnal Pendidikan karakter. Vol 2. No 3.

[12] UU RI Tahun 2005 tentang Guru dan Dosen serta UU RI No. 20 Tahun 2003 tentang Sisdiknas. 